\title{
TRAINING OF UNDERSTANDING SCIENCE PERSPECTIVE ON THE QURAN FOR THE INTELLIGENCE OF THE YOUNG GENERATION OF THE INDONESIAN NATION
}

\author{
Putri SURYANDARI ${ }^{*}$, Anggraeni DYAH ${ }^{2}$ and K. H. Fahmi BASYA ${ }^{3}$ \\ ${ }^{1}$ Budi Luhur University, Indonesia/ UIN Syarif Hidayatullah Jakarta, Indonesia \\ ${ }^{2}$ Budi Luhur University, Indonesia \\ ${ }^{3}$ Yayasan 74 Hafizun Alim \\ "putri.suryandari@budiluhur.ac.id
}

\begin{abstract}
Training is an educational activity to improve the ability and knowledge of a person or group of people. In this training activity, it was introduced to the millennial Muslim generation and recitation participants, regarding the development of Mathematics and Architecture in the Al-Quran. The development of Science and Architecture from time to time can be found in the Qur'an, so we can say that the Qur'an is multidimensional. Explanations and facts can be found in every dimension of human life, since the earth was created. This PPM material was obtained from the results of the study of the Qur'anic Science Perspective for the Intelligence of the Indonesian Young Generation. The method of implementing this dissemination is in two ways, namely, distributing questionnaires before and after the seminar and presenting research results. In the dissemination of the results of this study, it was carried out by showing the writings, readings, meanings of the verses of the Koran which explained the development of the space of human life from time to time. Its development can be traced from the stone age to the millennial era. So that the fostered partners understand the existence of Science and Technology in the Quran. After the training, the results of the evaluation showed that the participants were at the knowing stage and wanted to gain more knowledge. So that this training reaches the stage of getting a very good positive reaction.
\end{abstract}

Keywords: Science Perspective of Al Quran, multidimensional space, Islamic Architecture

\section{BACKGROUND}

Islam is a religion of Rahmatan lil alamin which means, as a form of mercy and compassion of Allah SWT, the gifts and favors given to his creatures throughout the universe. This grace belongs to Allah and was sent down through Islam to be enjoyed together. Therefore, the teachings of Islam which are embodied in the Qur'an, of course cover all fields of knowledge and life.

One of the fields of science that is important for human life, especially in meeting the need for housing, is in the fields of Mathematics and Architecture. So important is its presence in human life, so that architecture is included in one of the primary human needs, in addition to clothing and food.

Mathematics and architecture from time immemorial can be found in the Qur'an, so we can say that, the Qur'an is multidimensional. Explanations and facts can be found in every dimension of human life, since the earth was created(KH Fahmi Basya, 2010).

The partner is the 74 Hafizun Alim Foundation, which is a foundation engaged in education and socioreligion, especially the development of Qur'anic Science. This foundation carries all the studies that have been made by KH Fahmi Basya, which has been known for his best-selling books, namely Islamic Mathematics, One Million Phenomena, and Borobudur the Legacy of Prophet Solomon. His discoveries were in the form of proving the verses of the Qur'an, using a mathematical model called Islamic mathematics (Basya, 2007).

To introduce the Science of the Qur'an, it is necessary to conduct training or socialization of this knowledge in discussion groups assisted by partners. Problems from partners can be seen in the table below,
Table 1. Root of the Problems

\begin{tabular}{ll}
\hline \multicolumn{1}{c}{ Problems } & \multicolumn{1}{c}{ Root of the problems } \\
\hline $\begin{array}{l}\text { Do not know the science of } \\
\text { Architecture from the Qur'an, }\end{array}$ & $\begin{array}{l}\text { No basic knowledge of } \\
\text { Architecture }\end{array}$ \\
$\begin{array}{ll}\text { It is difficult to understand the } \\
\text { knowledge contained in the } \\
\text { Qur'an }\end{array}$ & $\begin{array}{l}\text { Differences in the formal } \\
\text { educational background of the } \\
\text { fostered partners }\end{array}$ \\
\hline
\end{tabular}

Source: Personal Analysis

Training is part of an education that aims to improve the special abilities or abilities of a person or group of people. Training is also a systematic activity that is carried out repeatedly (Reguning, 2017).

From some of the definitions above, it can be concluded that, training is an effort to improve abilities, acquire knowledge, and special abilities of groups of people. In the implementation of this training activity, those who will gain knowledge of Quranic Science, are not employees of a company, but Islamic communities and groups.

The purpose of training is essentially an answer to the problems faced by individuals or groups of people in obtaining and improving the abilities needed to do a job.

\section{METHODS}

According to Endah (2018) the types of training methods or training, namely lectures, discussions, demonstrations, exercises/practices, work instructions, case studies, games, role playing, in-tray, simulations and online learning. Due to the COVID-19 pandemic situation which is entering an emergency period, the implementation of PPKM causes the training system to be carried out using the Online Seminar or Webinar method. 
After the training, to find out the increase in knowledge of the participants, an evaluation was carried out. The results of the evaluation can be seen from, first is the reaction of the participants whether they really understand so they want to increase their knowledge again, second, learning At this stage aims to measure the learning outcomes that have been received by the participants. Whether these participants are able to accept the lessons that have been given or not, the third is the stage of knowing the behavior of the participants. Are their attitudes and behavior well developed or are they still passive, the fourth is Outcome, which is the desired goal of increasing participants' knowledge and behavior towards the training material (Konsultan manajemen kinerja, 2021).

\section{RESULTS AND DISCUSSION}

Solutions to solve problems based on the root cause of the fostered partners are:

1. To obtain science and technology regarding the existence of multidimensional space in the Qur'an, it begins by showing and explaining the letters and verses in the Qur'an that write about the existence of buildings, from the stone age to modern times and even after modern times.

2. To show the truth of the meaning of the verse, direct evidence is carried out on the spaciousness of the existence of buildings as described in the Qur'an, especially those in the environment around us (Java Indonesia).

The solution above can be seen in Table 2 below,

Table 2. Problems, Root Problems and Solutions

\begin{tabular}{lll}
\hline \multicolumn{1}{c}{ Problems } & \multicolumn{1}{c}{$\begin{array}{c}\text { Root of the } \\
\text { problems }\end{array}$} & \multicolumn{1}{c}{ Solution } \\
\hline $\begin{array}{l}\text { Do not know } \\
\text { the science of } \\
\begin{array}{l}\text { Architecture } \\
\text { from the } \\
\text { Qur'an, }\end{array}\end{array}$ & $\begin{array}{l}\text { No basic } \\
\text { knowledge of } \\
\text { Architecture }\end{array}$ & $\begin{array}{l}\text { Showing the } \\
\text { 4-dimensional character } \\
\text { of Architecture in the } \\
\text { Qur'an through the } \\
\text { explanation of the } \\
\text { multidimensional space in } \\
\text { the Qur'an }\end{array}$ \\
$\begin{array}{l}\text { It is difficult } \\
\text { to understand } \\
\text { the knowledge } \\
\text { contained in the } \\
\text { Qur'an }\end{array}$ & $\begin{array}{l}\text { Differences in the } \\
\text { formal educational } \\
\text { background of the } \\
\text { fostered partners }\end{array}$ & $\begin{array}{l}\text { Explain theoretically } \\
\text { and practically, in the } \\
\text { form of proof in the field, } \\
\text { regarding the evidence of } \\
\text { the verses in the Qur'an } \\
\text { that exist in this universe. }\end{array}$ \\
\hline
\end{tabular}

Source: Personal Analysis

\section{Activity Socialization}

The main socialization was carried out by distributing flyers through the online service Ngampooz. com. This media helps since the promotion of activities, registration of participants. Arranging the course of the event during the online webinar, up to the awarding of certificates and recording of activities.

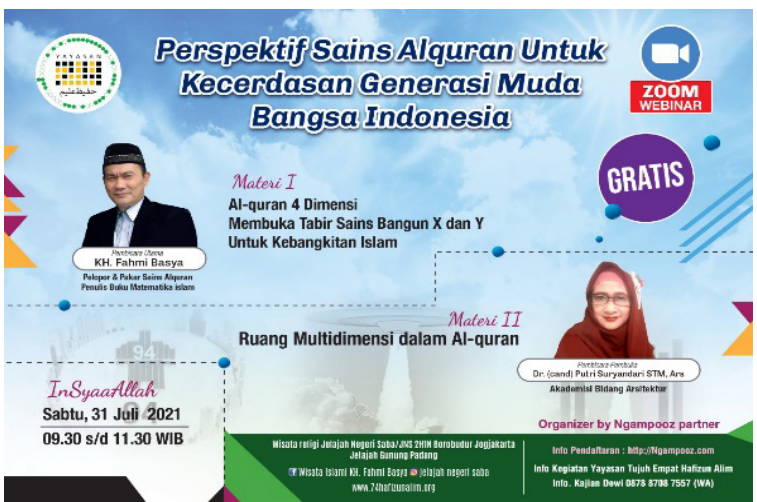

Picture 1. Flyer

Material Selection Activities According to Participants' Needs

The next stage is the selection of mutually supportive materials between the Budi Luhur PPM team and a partner, KH Fahmi Basya. The material from the opening speaker is expected to increase the participants' curiosity about AlQuran Science from Ustad KH Fahmi Basya.

\section{Training materials for opening speakers}

Multidimensional Space Architecture in Al Quran was chosen as the opening of the webinar. The material consists of an introduction to the science of Architecture through an understanding of the Qur'an which has a 4-dimensional character. Namely architecture according to the writings, readings, meanings and facts of the Qur'an.

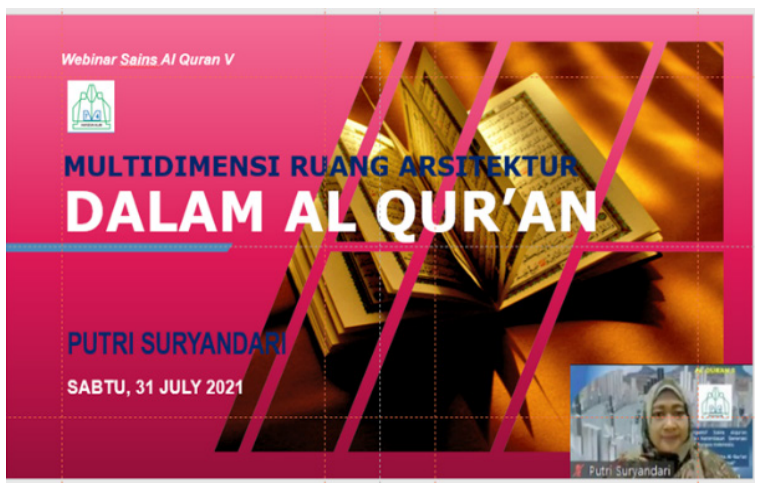

Picture 2. Materials for opening speakers

The material used as the opening paper describes the multidimensional architectural space in the Qur'an, the essence of which is as follows:

The Qur'an has written and shown facts about Multidimensional Space in the field of architecture. Starting from the past dimension to the end of time.

In the Qur'an other than in the verse it is written about the origin of architecture, it can be proven in fact the heritage of the building (Suryandari, 2019).

The Qur'an also has given a warning, how the damage and destruction of a nation will occur when tall buildings begin to bloom on earth. And will be the cause of the Day of Judgment that will come (Suryandari \& Hamka, 2020).

The Qur'an has also given the idea of penetrating space and time which is a TIME TUNEL phenomenon in the modern western world 


\section{Main training materials}

Ustad KH Fahmi Basya chose material that could arouse the curiosity of millennial youth with 4-Dimensional Al Quran material. Where to explain the Quran in mathematical language. How can the number of letters and the number of verses be coded for every event or activity of science and technology in the universe?

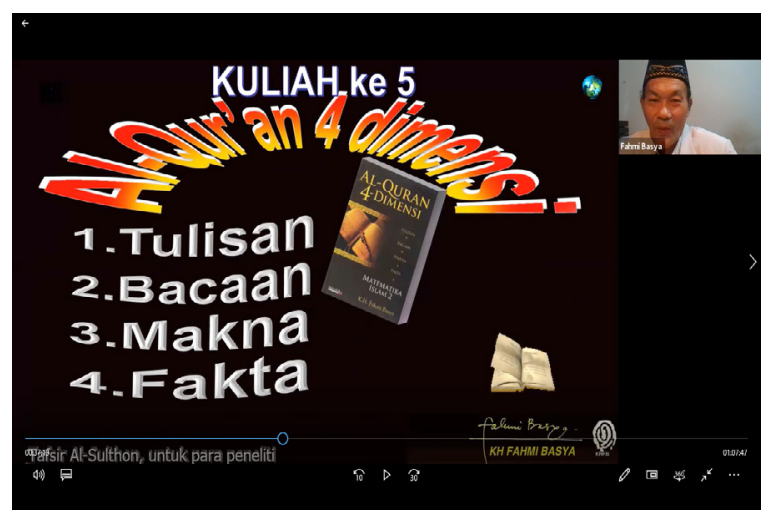

Picture 3. Materials for mainly speakers

\section{Activity Implementation Results}

In the implementation of this fifth Quran Science training activity, the event was held online via Zoom. This is due to the worsening pandemic conditions in early June, PPKM (Enforcement of Community Activity Restrictions) nationally was again strictly implemented, until mid-August 2021.

To gain knowledge from participants in general, shortly before the opening speaker's presentation, a questionnaire was distributed via Google form. This questionnaire aims to determine the participants' knowledge of the science of the Qur'an.

Of the total 137 participants who registered, 60 participants attended the webinar, which is $50 \%$ of the registrants. Meanwhile, 35 people filled out the Questionnaire, or half of the participants present.

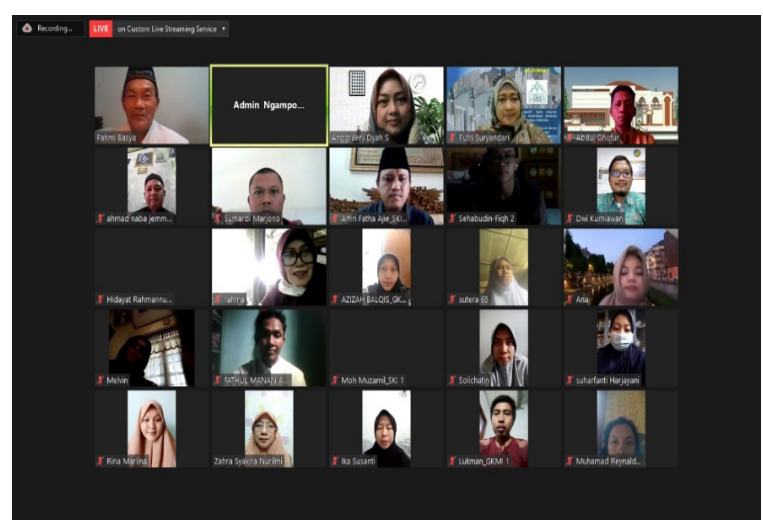

Picture 4. A photo of webinar participants

\section{Knowledge of participants before joining the webinar}

Asked about whether the participants were aware of the existence of Architecture in the Qur'an, almost 70\% said they did not know and did not understand. Like a wise with knowledge of science, especially mathematics in the Koran, only $40 \%$ who understand and know in general only.
All participants hope to gain knowledge and how to apply it in daily life.

\section{Knowledge of participants after joining the webinar}

Based on post-webinar questions, it was found that $100 \%$ were satisfied with this event and really hope that there will be another similar webinar. $50 \%$ of participants liked the material from Ustad KH Fahmi Basya regarding Code Language and the Pillars of the Quran, while others liked the overall material from the opening and main speakers, 20\% liked the architectural material.

The previous participants were only less than pursuing (40\%) who understood Mathematics and Architecture in the Quran, stating that this time they understood very well after the webinar was over.

All participants are very satisfied and most will recommend this event to their friends.

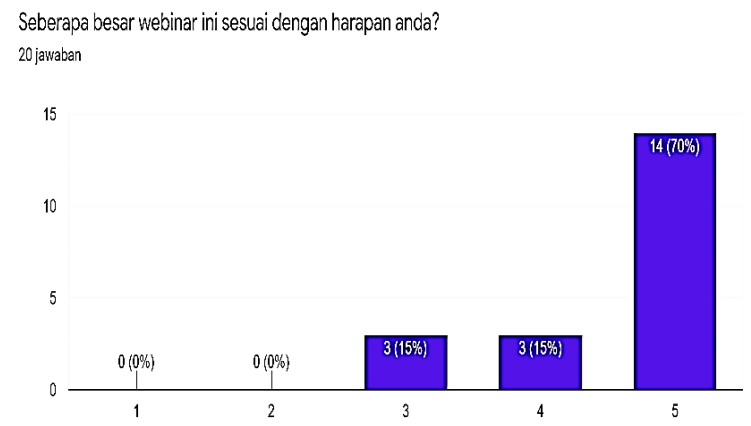

Picture 5. Participant satisfaction

Seberapa besar kemungkinan Anda merekomendasikan acara ini? 20 jawaban

15

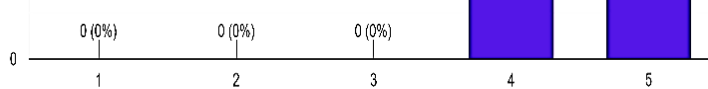

Picture 6. Possibility of recommending to Muslims

Based on the theory of the results of the evaluation of activities, the results have only reached level three, namely, first from the results of the table above, the reaction from the participants is that they understand so much that they want to increase their knowledge, secondly, at this stage based on the evaluation table, these participants are able to accept the lessons that have been given with ease. good, third is the behavior of the participants has developed well. While level four has not been reached because the evaluation results do not know the daily changes of the participants on an ongoing basis.

\section{CONCLUSION}

After carrying out the process of understanding the webinar participants and providing training on AlQuran Science, the conclusions of this activity are: 
1. Many people do not understand that architectural science and technology can be peeled from the meaning of the holy verses of the Koran

2. Society needs to prove that the buildings contained in the holy Qur'an can be found in fact through in-depth observation and research

3. People do not understand that in the Qur'an there is a multidimensional description of space, both past, present and future dimensions. Proof of the existence of the space through the remains of historical artifacts in the form of buildings that can be found through the research process.

4. Not many people know about the 4-dimensional characteristics of the Qur'an.

5. It is necessary to continue to be given training on the Scientific Perspective of the Qur'an.

\section{REFERENCES}

Basya, KF. (2007). Al Quran 4 Dimensi Tulisan, Bacaan, Makna, Fakta (1st ed.). Republika, Jakarta.
Basya, KF. (2010). Matematika Islam (Sebuah Pendekatan Rasional untuk Yaqin). Republika.

Konsultan Manajemen Kinerja. (2021). Cara dan Tahapan Mengukur Efektivitas Training atau Pelatihan. Retrieved August 18, 2021, from https:// manajemenkinerja.com/2021/05/cara-dan-tahapanmengukur-efektivitas-training-atau-pelatihan/

Reguning, ND. (2017). Pelaksanaan Pelatihan dan Pengembangan Karyawan di Koperasi Mahasiswa Universitas Negeri Yogyakarta Periode 2010-2011. Jurnal Ilmiah Manajemen Bisnis, 3(1), 12-18.

Suryandari, P. (2019). Sustainable Architecture Concept in Islam. $2^{\text {nd }}$ ICIIS 2019. 84-95, https://doi.org/10.4108/ eai.7-11-2019.2294605

Suryandari, P., \& Hamka, P. (2020). Al-Quran Perspective On Architectural Environmentally Friendly in the Aspect of Functions Building. 3rd ICIIS 2020, 1-11. 